\title{
THE ANALYSIS OF SCHOOL OPERATIONAL SUPPORT FUNDS' EFFECTIVENESS
}

\section{ANALISIS EFEKTIVITAS PENGGUNAAN DANA BANTUAN OPERASIONAL SEKOLAH}

\author{
By: \\ Esti Rahayu \\ Accounting Education Study Program Yogyakarta State University \\ estirahayu94@gmail.com \\ Mimin Nur Aisyah \\ Lecturer in Accounting Education Department Yogyakarta State University
}

\begin{abstract}
This research aims to determine the effectiveness of the use of BOS funds in SMK Negeri 2 Magelang in 2016 and its SWOT analysis. It was a descriptive research with quantitative and qualitative approach. Data collection methods used were interview and documentation. The research found that the use of BOS funds in SMK Negeri 2 Magelang in 2016 amounted to Rp1,279,348,659.00 from the planned Rp1,614,911,317.00 with the effectiveness of $79 \%$. According to the criteria of the Ministry of National Education (2009), the use of BOS funds is categorized as very effective because the percentage exceeds $70 \%$. The SWOT analysis provides several strategies, including : (1) using BOS funds to improve the competence of students and teachers and thus enhancing school's existence and achievement (S-O strategy), (2) administering training and capacity building of human resource managers (W-O strategy), (3) improving the internal control and communication with government related to BOS fund management (S-T strategy), and (4) increasing the supervision on the management of BOS funds (W-T strategy).
\end{abstract}

Keywords: Effectiveness, BOS funds, SWOT analysis, BOS strategy

Abstrak

Penelitian ini bertujuan untuk mengetahui efektivitas penggunaan dana BOS di SMK Negeri 2 Magelang tahun 2016 beserta analisis SWOT nya. Penelitian ini merupakan penelitian deskriptif dengan pendekatan kuantitatif dan kualitatif. Metode pengumpulan data yang digunakan adalah wawancara dan dokumentasi. Hasil dari penelitian ini yaitu penggunaan dana BOS tahun 2016 di SMK Negeri 2 Magelang secara keseluruhan sebesar Rp1.279.348.659,00 dari perencanaan sebesar Rp1.614.911.317,00 dengan efektivitas sebesar 79\%. Berdasarkan kriteria Departemen Pendidikan Nasional (2009), hal tersebut menunjukkan kategori sangat efektif karena persentasenya melebihi 70\%. Analisis SWOT menghasilkan beberapa strategi yaitu: (1) menggunakan dana BOS untuk meningkatkan kompetensi siswa dan guru sehingga bisa meningkatkan eksistensi dan prestasi sekolah (stategi $S-O$ ), (2) mengadakan pelatihan dan peningkatan SDM pengelola (strategi $\mathrm{W}-\mathrm{O}$ ), (3) meningkatkan kontrol internal dan komunikasi dengan pemerintah terkait pengelolaan dana BOS (strategi S-T), serta (4) melakukan peningkatan pengawasan pengelolaan dana BOS (strategi $W-T$ ).

Kata kunci: Efektivitas, dana BOS, analisis SWOT, strategi penggunaan BOS 


\section{INTRODUCTION}

The government has a serious concern about 9-year compulsory education and education budget allocation. Peraturan Pemerintah Nomor 48 Tahun 2008 about Education Funding mentioned that education funding is a shared responsibility between central government, local government, and society. One of the embodiments of government responsibility towards the funding of education includes school operational support funds (BOS program).

BOS program was started in July 2005. At the beginning, the elementary schools, junior high schools, and other equal levels of education were the main focus of BOS program. BOS program has provided a significant role towards the acceleration of 9-year compulsory education program. The success of BOS program implementation can be seen from alleviation compulsory education in accordance with the target or even faster than the target.

The 9-year compulsory education program has been successfully completed with the indicator of rough participation rate as known as Angka Partisipasi Kasar (APK) of Junior High School reaches $91.17 \%$ by 2015 . The consequence of the success of the 9-years compulsory education program is the growing number of students of junior high school graduates which must be accommodated by SMA/SMK/Equal. Meanwhile, the availability of classrooms in the secondary SMA/SMK/Equal is not enough according to the number of students of junior high school graduates/all equal to each other. As a result, many graduates of junior high school/equal cannot continue to SMA/SMK/Equal either because of constraints of the capacity of SMA/SMK/Equal or inability to pay tuition fees. Therefore, the government encourages to accelerate construction of secondary education through initiating secondary education universal as known as Pendidikan Menengah Universal (PMU), which is the first step towards the implementation of stub program of 12-years compulsory education (Permendikbud, 2013). One of the goals of PMU program is giving the opportunity to all society, especially those that cannot afford economically to get secondary education services.

BOS fund for SMK is a government program in the form of direct funding to SMK both public and private to help school operational cost of nonpersonnel. According to the Government Rules No 48/2008 about Education Funding, the cost of non-personnel is the cost of materials or educational equipment supplies, and indirect costs in the form of power, water, telecommunications services, maintenance of facilities and infrastructure, ground transportation, overtime money, consumption, taxation, and others. The amount of fund received by the school is calculated based on the number of school's students at each school and then multiplied by support unit cost. The Management of the BOS fund for SMK shall be guided by the technical instruction of BOS for SMK published by Direktorat Pembinaan SMK. In 2016, BOS fund for SMK that received by an education unit was managed to fund 17 activity components in the order of priority.

SMK Negeri 2 Magelang is one of the secondary schools which receive BOS fund. The results of observation and interview to the budget team leader of BOS fund SMK Negeri 2 Magelang on 5th December 2016 obtained information about the management of BOS fund. There are some problems in the management of BOS fund. For example, the delay in the disbursement of the BOS fund, the BOS fund manager who has low quality, and the lack of participation of the parties concerned with BOS funds. Therefore, the policy in allocating BOS fund 2016 at SMK Negeri 2 Magelang is questionable. 
Based on above description and the various problems that exist, researcher is interested to conduct a study entitled "The Analysis of School Operational Support Funds' Effectiveness at SMK Negeri 2 Magelang in 2016".

\section{RESEARCH METHOD \\ Research Design}

This research was a descriptive research with qualitative and quantitative approach. The qualitative approach explained the completed data of BOS fund management and its SWOT data. A quantitative approach generated the percentage of the use of BOS funds.

\section{Place and Time Research}

This research was conducted at SMK Negeri 2 Magelang which located at $\mathrm{Jl}$. Ahmad Yani number 135, Kramat Selatan, Magelang Utara, Magelang. This research was conducted from December 2016 to December 2017.

\section{Subject and Object Research}

The research subject include the principal, BOS management team, school committee and related parties using BOS fund at SMK Negeri 2 Magelang, whereas the research object is the use of BOS in Vocational High School (SMK) reviewed from 17 financing components based on BOS's technical instruction for SMK in 2016 along with the SWOT (Strengths, Weaknesses, Opportunities, and Threats) analysis.

\section{Research Procedure}

The effectiveness of planning and realization of BOS funds in 2016 were analyzed by calculating the percentage of 17 financing components in technical instruction. Interviews with BOS managerial and related parties were conducted to complete the documents. Those data were further analyzed to produce information on BOS fund's use effectiveness, SWOT analysis and some development strategies.

\section{Types of Data}

The data that were collected in this research consisted of two data, qualitative and quantitative data. Qualitative data was derived from interview to obtain the information of BOS fund managerial procedures and implementation. Quantitative data include the financial data of BOS funds' planning and realization.

\section{Data Collection Technique}

The data collection technique in this research used interview and documentation. The interviews involved the school principal, treasurer of BOS, the budget team of BOS, and its related parties. The documentation included the RKAS, RAB BOS fund, a realization of the fund, and the fund usage.

\section{Research Instrument}

Data collection instruments that was used in this research were interview guidelines and documentation guidelines.

\section{Data Analysis Technique}

a. Quantitative Data Analysis

Quantitative data was obtained from the budget plan and the report on the realization of the use of BOS funds. The technique of calculating the percentage of the effectiveness of the use of BOS funds will be analyzed using the formula:

$$
\begin{aligned}
& \mathrm{P}=\frac{\mathrm{f}}{\mathrm{N}} \times 100 \% \\
& \text { Description: } \\
& \mathrm{P}=\text { Percentage } \\
& \mathrm{F}=\text { Frequency that is being sought } \\
& \mathrm{N}=\text { The number of frequency } \\
& \quad \text { (Anas Sudijono, 2012: 43) }
\end{aligned}
$$

The effectiveness of the BOS funds 2016 at SMK Negeri 2 Magelang on 17 components is classified into three levels of effectiveness criteria, as shown in table 1. 
Table 1. Effectiveness Criteria of BOS

\begin{tabular}{|c|c|}
\hline $\begin{array}{c}\text { Percentage of } \\
\text { Financial } \\
\text { Performance }\end{array}$ & Criteria \\
\hline$>70 \%$ & Very Effective \\
\hline $70 \%$ & Effective \\
\hline$<70 \%$ & Ineffective \\
\hline
\end{tabular}

Source: Ministry of National Education RI, 2009

b. Qualitative Data Analysis

Data analysis in qualitative research started at the time of the data collection process took place, and after the completion of data collection within a certain period. Qualitative data comes from the result of interview. The data were analyzed with Miles and Huberman model, which include: (1) reduction of data, display/presentation of the data, and (3) take the conclusions and then verified. It can be seen in the figure 1 below.

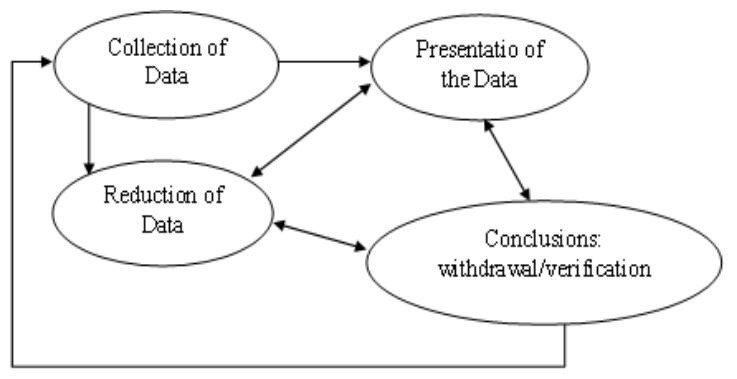

Source: Djunaidi Ghony and Fauzan Almanshur, 2012:306

Figure 1. Miles and Huberman Analysis Model

The qualitative data was presented in the SWOT analysis. It was analized further for SWOT strategies. It can be seen in the figure 2 below.

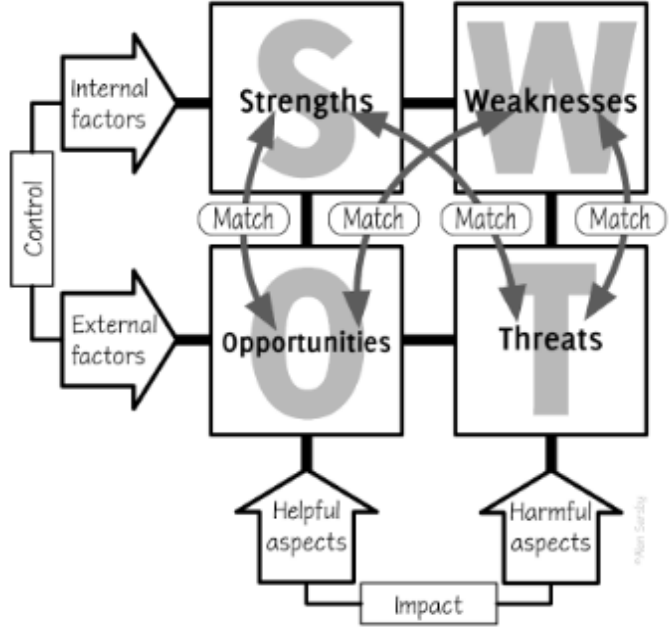

Source : Alan Sarbsy, 2016:12

Figure 2. Potential Matching Between Harmful and Helpful Factors

\section{RESEARCH RESULT AND DISCUSSION \\ The Effectiveness on the Use of BOS Funds}

SMK Negeri 2 Magelang make the planning of BOS funds twice a year. In the first semester, with a total of 1,071 students, BOS funds receive planned for Rp749,700,000. The source of income is distributed into 16 budget items contained in the technical instructions. There is one missing budget item. It is the costs of the security and safety insurance of education unit and disaster relief. The budget leader said that the budget is not prioritized because the school's position is outside the disaster-prone area.

In the second semester, BOS funds was planned to receive $\mathrm{Rp} 744,100,000$. It was calculated based on the amount of data of second and third grade in the new academic year and new students in first grade with 1,063 students. However, the amount of BOS funds that can be used is Rp865,211,317 because there is a remaining BOS fund in the first semester amounted of Rp121,111,317.

SMK Negeri 2 Magelang receives BOS funds quarterly. BOS fund received in the first quarter amounted to Rp374,850,000. Not all funds have been 
$1-11$

used in this period. In the report, it is written that the remaining funds in the first quarter was Rp44,840,589. This shows that the use of BOS funds amounts to Rp330,009,411 which has spread into 10 of the 17 components of the BOS fund budget.

Total funds that can be used in the second quarter amounts to Rp419,690,589 which consists of Rp374,850,000 from the receive of the second quarter and the remaining funds of the first quarter amounting to Rp44,840,589. The funds were distributed in 13 of the 17 budget items in the technical instructions of the use of BOS funds. The remaining BOS funds up to the second quarter are Rp121,111,317.

The third quarter, BOS fund receipt amounted to Rp349,650,000. The funds that can be used comes from the disbursement of third quarter BOS funds and the remaining BOS funds in the previous quarter amounted of Rp495,961,317. Some of these funds can be distributed in 8 of 17 budget items of Rp229,997,088 and leave funds of Rp265,964,229.

The fourth quarter of 2016, BOS fund receipts amounting to Rp374,850,000. The BOS funds usage amounted of Rp615,614,229 came from this quarter's disbursement and the remaining in the previous quarter amounted to Rp265,964,229. At the end of 2016, BOS funds still remain for Rp194,851,341. The remaining funds can be used as an opening balance in the following year.

Based on the planning and realization data above, it can be summarized in table 2 below along with the percentage of its realization.

Table 2. Recapitulation of the Effectiveness of the Use of BOS Funds in 2016

\begin{tabular}{|c|c|c|c|c|}
\hline No & Component & $\begin{array}{l}\text { Amount of } \\
\text { Planning }\end{array}$ & $\begin{array}{l}\text { Amount of } \\
\text { Realization }\end{array}$ & $\begin{array}{l}\text { Realization } \\
\text { Percentage }\end{array}$ \\
\hline 1 & $\begin{array}{l}\text { Procurement of textbooks/books } \\
\text { supporting learning/reading books }\end{array}$ & $200,000,000$ & $214,845,000$ & $107 \%$ \\
\hline 2 & $\begin{array}{l}\text { Financing the management of } \\
\text { educational units }\end{array}$ & $130,000,000$ & $35,202,800$ & $27 \%$ \\
\hline 3 & $\begin{array}{l}\text { Procurement of tool supplies of } \\
\text { practical learning }\end{array}$ & $81,300,000$ & $41,120,000$ & $51 \%$ \\
\hline 4 & $\begin{array}{l}\text { Procurement of practical learning } \\
\text { supplies }\end{array}$ & $260,000,000$ & $165,459,500$ & $64 \%$ \\
\hline 5 & Resources and services subscription & $216,311,317$ & $183,367,859$ & $85 \%$ \\
\hline 6 & Organizing learning evaluation & $130,000,000$ & $132,353,000$ & $102 \%$ \\
\hline 7 & $\begin{array}{l}\text { Organizing extracurricular/student's } \\
\text { coaching and intracurricular } \\
\text { activities }\end{array}$ & $30,000,000$ & $66,808,000$ & $223 \%$ \\
\hline 8 & $\begin{array}{l}\text { Maintenance and care of the } \\
\text { facility/infrastructure of education } \\
\text { unit }\end{array}$ & $225,000,000$ & $165,148,300$ & $73 \%$ \\
\hline 9 & $\begin{array}{l}\text { The activities of new students } \\
\text { registration }\end{array}$ & $15,000,000$ & $12,140,000$ & $81 \%$ \\
\hline
\end{tabular}




\begin{tabular}{|c|c|c|c|c|}
\hline No & Component & $\begin{array}{c}\text { Amount of } \\
\text { Planning }\end{array}$ & $\begin{array}{l}\text { Amount of } \\
\text { Realization }\end{array}$ & $\begin{array}{l}\text { Realization } \\
\text { Percentage }\end{array}$ \\
\hline 10 & $\begin{array}{l}\text { Organizing the competence and } \\
\text { vocational certification activities }\end{array}$ & $120,000,000$ & $115,886,800$ & $97 \%$ \\
\hline 11 & $\begin{array}{l}\text { Organizing the industrial working } \\
\text { practices (Prakerin)/fieldwork } \\
\text { practices (PKL) in domestic area } \\
\text { and internships }\end{array}$ & $35,000,000$ & $9,150,000$ & $26 \%$ \\
\hline 12 & Development of school references & $12,100,000$ & $16,045,000$ & $133 \%$ \\
\hline 13 & $\begin{array}{l}\text { Improvement of learning process } \\
\text { quality }\end{array}$ & $40,000,000$ & $66,040,700$ & $165 \%$ \\
\hline 14 & $\begin{array}{l}\text { Managing the ICT-based education } \\
\text { unit services }\end{array}$ & $15,200,000$ & $5,031,700$ & $33 \%$ \\
\hline 15 & $\begin{array}{l}\text { Costs of the security and safety } \\
\text { insurance of education unit and } \\
\text { disaster relief }\end{array}$ & - & - & $0 \%$ \\
\hline 16 & $\begin{array}{l}\text { Purchasing the computer equipment } \\
\text { for learning activities }\end{array}$ & $104,000,000$ & $50,750,000$ & $49 \%$ \\
\hline 17 & Costs of preparation and reporting & $1,000,000$ & - & $0 \%$ \\
\hline & Total & $\begin{array}{c}1,614,911,31 \\
7\end{array}$ & $\begin{array}{c}1,279,348,65 \\
9\end{array}$ & $79 \%$ \\
\hline
\end{tabular}

*Sources of funds in the second semester plan is to get additional funds in the first semester of Rp121,111,317 Source: Primary Data

Based on the table above, it can be seen that the use of BOS funds in 2016 as a whole amounted to Rp1,279,348,659, from the planning of Rp1,614,911.317. with the effectiveness of $79 \%$. According to the criteria of the Ministry of national education (2009), it shows that the use of BOS funds in 2016 as a whole is very effective because the percentage exceeds $70 \%$. The existence of indication of delay in disbursement of BOS funds caused the absorption of funds only about $79 \%$.

Viewed from each component, there is one component that is not budgeted. It is the costs of the security and safety insurance of education unit and disaster relief. Based on interviews, the allocation of BOS funds is based on the needs. If there is any idle components, then funds can be allocated to the other components. For example, the costs of preparation and reporting was budgeted for $\mathrm{Rp} 1,000,000$ but it was not used. There are 6 components of financing that their realization were less than $70 \%, 5$ components of financing that their realization exceeds the amount of planning, and 4 components have the range of percentage use of $70 \%-100 \%$.

From the description, it can be seen that there is a cross-subsidy between components of the budget. When an expenditure has been budgeted, but it can not be realized for any reason, such as a shorter implementation time or other reasons, the funds can be used for other components as needed.

\section{Strengths, Weaknesses, Opportunities, and Threats of BOS Funds}

a. SWOT Analysis

SMK Negeri 2 Magelang is one of the vocational secondary school that get BOS funds since 2013. The BOS fund management regulations from the 
government starting 2013 up to now is changing and always shows an improvement both in terms of funding activities and administrative management. The changing of regulation is accompanied by routine socialization from the government every year, both for the responsible and administrative management of BOS in school. Despites the previous effort, there are still many obstacles faced in managing BOS funds such as the distribution of BOS funds from the central government and the accountability in each school, including SMK Negeri 2 Magelang.

The ongoing BOS funds for SMA/SMK/Equal for about 5 years, still need improvement and enhancement in terms of technical and policy provided either from the government or the school that managing BOS fund. In case of improvement and enhancement, some effort can be attempted by knowing the strengths, weaknesses, opportunities, and threats of the BOS funds in table 3 below.

Table 3. SWOT Description of BOS Funds

\begin{tabular}{|c|c|}
\hline Strengths & Weaknesses \\
\hline $\begin{array}{l}\text { 1. Help out the tuition fees paid by students. } \\
\text { 2. Guarantee the availability of funding source } \\
\text { of activities. } \\
\text { 3. Guarantee the availability of each student's } \\
\text { book. } \\
\text { 4. There is a clear BOS fund management } \\
\text { team and their respective responsibilities. } \\
\text { 5. There is a control system that is used to } \\
\text { monitor the use of BOS funds. } \\
\text { 6. There is a centralized school data system. } \\
\text { 7. There is coordination between the school } \\
\text { 8. Producing students with specialize skills. } \\
\text { 9. Facilitating programs to improve teachers' } \\
\text { and students' competence. }\end{array}$ & $\begin{array}{l}\text { 1. The dependence of the school with } \\
\text { BOS funds. } \\
\text { 2. The reporting delay by fund users. } \\
\text { 3. Technical instructions are less } \\
\text { communicative that cause a multi } \\
\text { perception. } \\
\text { 4. Differences in the period of BOS } \\
\text { funds recording with the academic } \\
\text { period. } \\
\text { 5. Lack of socialization by school BOS } \\
\text { fund manager caused the fund users } \\
\text { don't understand the whole of } \\
\text { technical instruction. } \\
\text { 6. Accountability of BOS funds is } \\
\text { complicated. } \\
\text { 7. Low level of understanding of BOS } \\
\text { treasurer in following the } \\
\text { development of the technical } \\
\text { instructions. }\end{array}$ \\
\hline Opportunities & \begin{tabular}{|c|} 
Treaths \\
\end{tabular} \\
\hline $\begin{array}{l}\text { 1. Supporting the school work programs. } \\
\text { 2. Government policy on the development of } \\
\text { variations in the use of BOS funds in the } \\
\text { technical instructions. }\end{array}$ & $\begin{array}{l}\text { 1. The delay in the distribution of BOS } \\
\text { funds. } \\
\text { 2. The technical instructions are less } \\
\text { flexible. }\end{array}$ \\
\hline $\begin{array}{l}\text { 3. Improve the existence and achievements of } \\
\text { the school. } \\
\text { 4. There are prospective students who will } \\
\text { continue to SMK. } \\
\text { 5. Increase in the amount of BOS funds which } \\
\text { is given annually. } \\
\text { 6. There is coordination, dissemination, and }\end{array}$ & $\begin{array}{l}\text { 3. Government policy to abolish BOS } \\
\text { funds. } \\
\text { 4. Sanctions from the government when } \\
\text { management does not fit the rules. } \\
\text { 5. There is a misappropriation of BOS } \\
\text { funds that may occur at every level. } \\
\text { 6. Competition with similar schools. }\end{array}$ \\
\hline
\end{tabular}


training regularly from the government.

7. There is a regular supervision from the government.

8. The development of IT especially education that can streamline school activities.

9. There are companies that need vocational graduates.

10. There are companies that are willing to accept students practice.

11. There are academic and non-academic competitions at both regional and national levels.

Source: Primary Data with Modification

b. SWOT Strategies

BOS fund management that has been implemented for approximately 5 years, especially in SMK Negeri 2 Magelang, has some strengths, weaknesses, opportunities, and threats. Based on SWOT data in table 11, can be analyzed strategies that can be used both internal and external strategies. The existence of the strengths can be used to take advantage of opportunities (S-O strategy) and avoid the existing threats (W-O strategy). The weaknesses can be eliminated/minimized by taking advantage of existing opportunities (S-T strategy). By minimizing the weaknesses are also able to avoid the existing threat (W-T strategy). The strategies will be presented in the following table 13 .

\section{Table 4. SWOT Analysis and Strategy of BOS Fund}

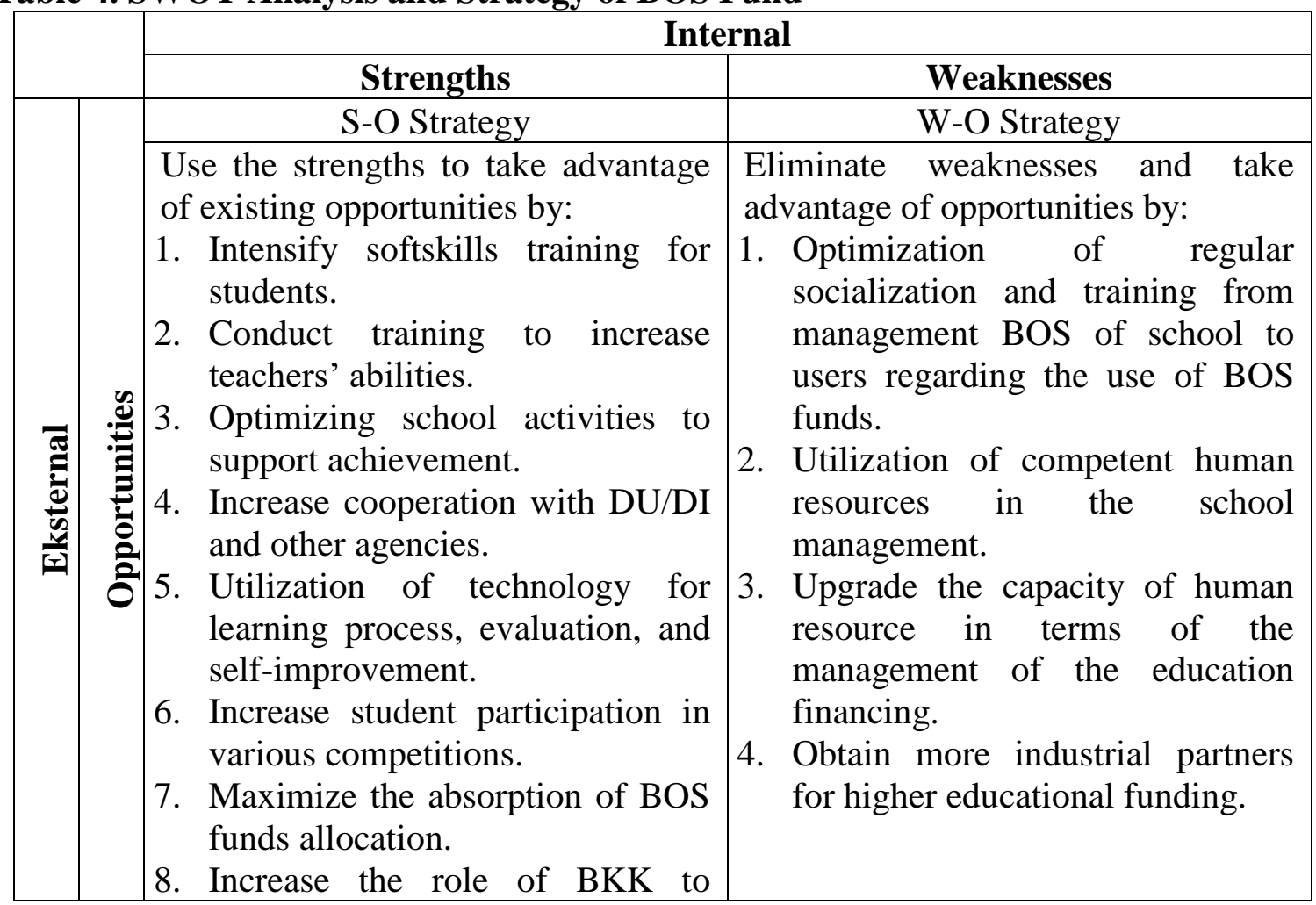




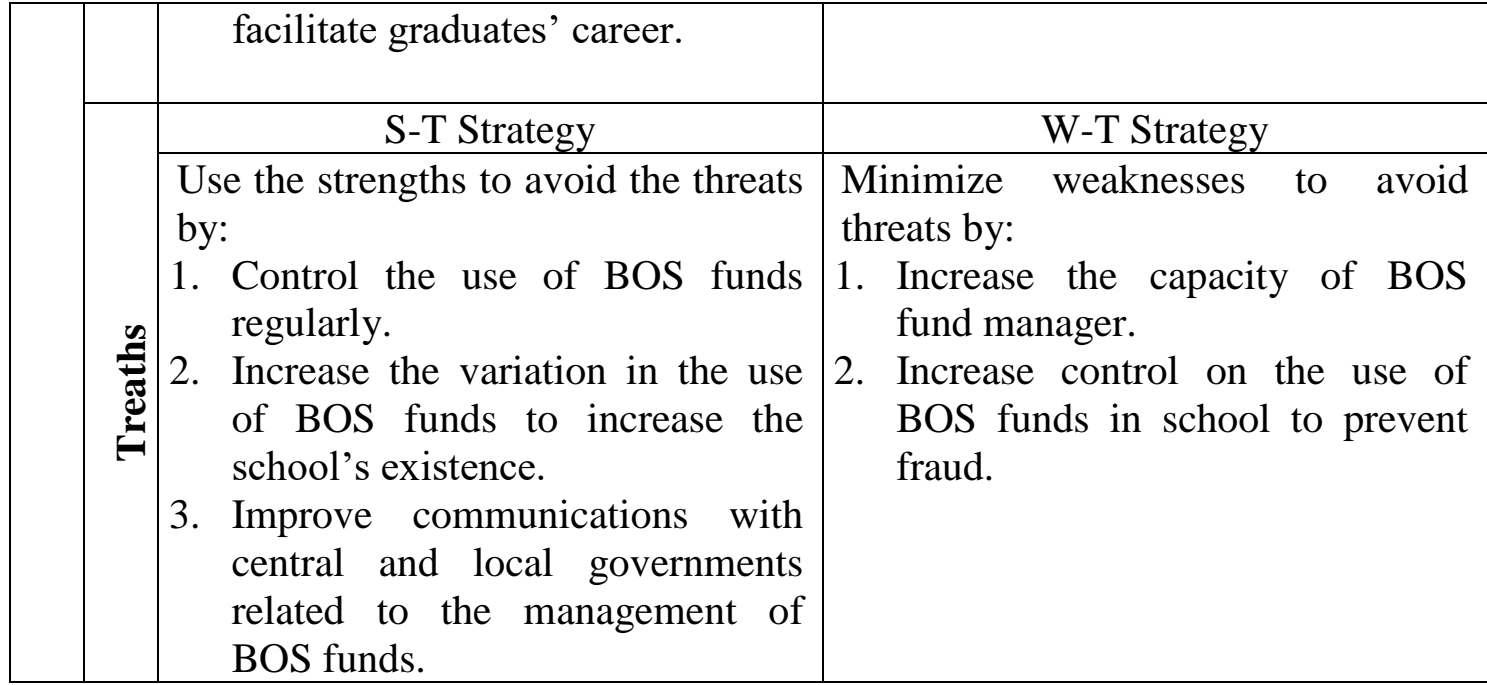

Source: Primary Data with Modification

\section{CONCLUSION AND SUGGESTION Conclusion}

Based on the results of research and the discussion that has been described previously, the conclusion is as follows:

a) The effectiveness of the use of BOS funds in 2016 as a whole is implemented very effectively with the percentage of $79 \%$. There is 1 component that is not budgeted, 1 component is budgeted but not used, 6 components with a percentage of realization under $70 \%, 4$ components of budget realization between $70 \%-100 \%$, and 5 components with the realization above $100 \%$. The use of each component of BOS funds is crosssubsidized based on needs.

b) The strengths of BOS funds, among others: help out the tuition fees paid by students; guarantee the availability of funding source of activities; guarantee the availability of each student's book; there is a clear BOS fund management team and their respective responsibilities; there is a control system that is used to monitor the use of BOS funds; there is a centralized school data system; there is coordination between the school management team and fund users; producing students with specialize skills; and facilitating programs to improve teachers' and students' competence.

c) The weaknesses of BOS funds, among others: the dependence of the school with BOS funds; the reporting delay by fund users; technical instructions are less communicative that cause a multi perception; differences in the period of BOS funds recording with the academic period; lack of socialization by school BOS fund manager caused the fund users don't understand the whole of technical instruction; accountability of BOS funds is complicated; and low level of understanding of BOS treasurer in following the development of the technical instructions.

d) The opportunities of BOS funds, among others: supporting the school work programs; government policy on the development of variations in the use of BOS funds in the technical instructions; improve the existence and achievements of the school; there are prospective students who will continue to SMK; increase in the amount of BOS funds which is given annually; improve the competence of teachers and students; there is coordination, dissemination, and training regularly from the government; there is a regular supervision from the government; the development of IT especially education 
that can streamline school activities; there are companies that need vocational graduates; there are companies that are willing to accept students practice; and there are academic and non-academic competitions at both regional and national levels.

e) The threats of BOS funds, among others: the delay in the distribution of BOS the funds; the technical instructions are less flexible; government policy to abolish BOS funds; sanctions from the government when management does not fit the rules; there is a misappropriation of BOS funds that may occur at every level; dan competition with similar schools.

f) The S-O strategy is conducted by using BOS funds to improve the competence of students and teachers and thus enchanging school's existence and achievement.

g) The W-O strategy is administering training and capacity building of human resource managers.

h) The S-T strategy is improving internal control and communication with government related to BOS fund management.

i) The W-T strategy is conducted by increasing the supervision on the management of BOS funds.

\section{Suggestion}

Based on the conclusion above, in an effort to improve the management of BOS funds are submitted suggestions as follows:

a) For Central Government (Directorate of Mentoring of SMK, Directorate of Secondary Education)

1) Create a simpler reporting and administrative format that makes it easier to manage BOS funds.

2) Evaluate the distribution of BOS funds to schools on a regular basis, to quickly find a solution to the delay in BOS funds to schools.

3) Update the technical instructions in accordance with needs and more flexible usage. It is hoped that the variation and policy on the use of BOS funds can adjust to the needs, such as policies about library book ownership by students, and the addition of the components of the use of funds to improve student achievement and welfare of educational personnel.

4) Conduct regular training and technical assistance for BOS managers, so that they are able to perform their duties in accordance with the technical instructions properly, considering the regulation on the use of BOS funds that are changed annually.

b) For School

1) Socialize the use of BOS funds comprehensively to the users of fund and parents.

2) Improve BOS funds planning through need analysis and appropriate school programs.

c) Next researcher may involve the district education office and parents as respondents to obtain a more comprehensive perspective of stakeholders.

\section{REFERENCES}

Alan Sarsby. (2016). SWOT Analysis, A Guide to SWOT for Business Studies Students. England : Leadership library.

Anas Sudijono. (2012). Pengantar Statistik Pendidikan. Jakarta: Rajawali Pers.

Badan Pusat Statistik. (2016). Angka Partisipasi Kasar (APK) tahun 20032015. Accessed from www.bps.go.id on December 10th, 2016 on 08.00 WIB. 
Gede Andreyan Semara Bhawa, dkk. (2014). Efektivitas Pengelolaan Dana Bantuan Operasional Sekolah (BOS) pada Sekolah Dasar di Kecamatan Sukada. Undergraduate Thesis. Universitas Pendidikan Indonesia.

Kementerian Pendidikan dan Kebudayaan. (2013). Peraturan Menteri Pendidikan Nasional No. 80 Tahun 2013 tentang Pendidikan Menengah Universal.

M. Djunaidi Ghony dan Fauzan. (2012). Metodologi Penelitian Kualitatif. Yogyakarta: Ar Ruzz Media.

Sekretaris Negara Republik Indonesia. (1990). Undang-Undang Nomor 29 Tahun 1990 tentang Pendidikan Menengah Peraturan Pemerintah (PP) Republik Indonesia Nomor 48 Tahun 2008 tentang Pendanaan Pendidikan.

Suci R.M Koesomowidjojo. (2017). Balance Scorecard, Model Pengukuran Kinerja Organisasi dengan Empat Perspektif. Jakarta: Raih Asa Sukses. 